\title{
Sound migrations in Portuguese: Cultural REPRESENTATIONS OF THE PORTUGUESE DIASPORA IN THE BRAZILIAN RADIO
}

\author{
Teresa Alves
}

\begin{abstract}
Portuguese language is a multiple sounds language. Regarding the different possible accents, Portuguese-speaking way seems to be one of the language's most relevant characteristics. Radio, as a sound media, is able to represent this diversity. There are several radio shows produced towards the Portuguese culture diaspora. In this paper, we will analyse radio shows produced in Brazil for the Portuguese diaspora: strategic differential, representation ability and the way they relate to diaspora and migrant communities. Looking at Portugal and Brazil as casestudies, we will reflect on post-colonial relationships between the two countries, based on radio as a medium able to undertake the decolonial turn.
\end{abstract}

\section{Keywords}

Radio; diaspora; Lusophone culture; migration flows

\section{INTRODUCTION}

Looking at migrations as cultural products of a globalized world, it takes us through an overview of media and the way it has been coming along the history of migrations. Embracing this demand, this article reflects on the relationship betweeen radio's mediatic power, the Portuguese diaspora and Lusophone culture in migratory contexts. Because we are dealing with a mutant alive organism, we will observe differences in the relationship between the many diaspora generations and Lusophone culture radio shows targetting the immigrant community, considering not only the diaspora's approach towards the traditional FM radio model, but also the growing digitalization of lifestyle in globalized societies. On the one hand, FM still outstands with relevant audience and high listeners' fidelization levels. On the other hand, digital seems to be the main source of media connection to these communities' country of origin.

The world map image is one of globalization's main 'eikons' and it reveals the way human beings have looked at each other through geografic dimension. The planisphere was designed according to the Mercator projection in 1569, and has been the most used projection until today. It has been widely criticized, both because it unveils a eurocentrist view - displaying Europe in the centre - and also due to the distortion of continents' real dimensions, conveying greater visual impact not only to Europe but also to the United States of America. The way we imagine the planet's visual layout - even tough it intends to be a universal and objective image, transversal to all of the nations - represents a way 
of thinking that is designed according to the world's hegemonic powers: the West and the North.

This way of disposing continents in the world map reveals a westernized point of view. Therefore, we could consider that, since the European decolonization project has ended, some countries have been "remappped". This remapping process has been happening through rewesternization and dewesternization. Rewesternization has been taking place almost all over the world since the rise of North-American culture as the hegemonic culture in the second half of the 2oth century. This phenomena was naturally accelerated by Internet and the easy access to North-American references across the planet, massifying possibilities of adopting a mainstream culture, even in countries where information was harder to get. As for dewesternization, it essentially occured in developing economies that emerged in a new post-colonial world layout. Economic organizations, such as BRICS', gathering powerful economies, development levels closer to the West and different political spheres, represent an example of decolonial organizations. These countries do not have a common language, common history nor a common cultural memory, they just share an idea of a past marked by Western incursions. When united as a group of geostrategical nations of the South - in opposition to other organizations, such as the $\mathrm{G}_{7}$ or G8 -, they challenge the more established economies from the North.

The objective of rewesternization and deconolozation proceses reveals a detachement as regards the hegemonic model represented by colonizing countries (Portugal, Spain, France, United Kingdom, and Germany) and its sound materialisms: its respective languages. Decolonizating and, consequentely, rewesternizating culture, would sart from non western cognitive principles and decolonizing culture would be even more relevant in the moment of decolonizing than in altering economic and political status quo (Mignolo, 2013):

In both cases, however, both ways of thinking and acquiring knowledge happen in six imperial Western and European languages (Italian, Castilian, Portuguese, French, English and German), founded in two classic languages, Greek and Latin. Therefore, dewesternization and decoloniality of knowledge in 'culture' carry the need of thinking in non-Western languages and categories (in the restrict sense of the six mentioned languages and their sources) and also through accumulated knowledge in the West which is distributed all over the planet. Afterall, this order reflects a cultural dewesternization (more than in political economy order). (Mignolo, 2013, s.d.)

Both in the case of rewesternization and dewesternization, there is an urge for the release from na hegemonic model represented by colonizing countries (Portugal, Spain, France, England and Germany) and their materialized sounds: their languages.

\footnotetext{
' BRICS is the English acronym for the following set of countries: Brazil, Russia, India, China and South Africa. This set of countries puts together $30 \%$ of the world's richness (RT, 2014). They are considered to be the most powerful emergent economies of the planet, all of them considered to be part of the South by the field of Area Studies (even if Russia and China are geografically located in the North).
} 
Decolonizing is, consequently, dewesternizing culture starting from non-western linguistic and cognitive proceedings; dewesternizing culture would become even more important for the decolonial act than even changing the economical and political status quo (Mignolo, 2013).

In these terms, considering their historical past, both Portugal and Brazil would belong, to certain extent, to distinct plans of hegemonic framing of colonialist thought. Portugal would be on the North rewestenized side, i.e., culturally reconfigured by the almost global influence of the USA, as a country geographically and politically connected to the global capitalism of that side of the world. Moreover, Brazil would fit the South dewesternized side, particularly in the Latin American economies' context of socialist inspiration. However, we will also have to consider the growing introduction of NorthAmerican mainstream culture, especially among the "new" middle class, enlarged and solidified during Lula da Silva's governance2. This globalizing tendency can be explained, not only by the growing access of middle class to credit, and consequently, to digital technological items (computers, tablets and smartphones) alowed by generalized increase of the Brazialians' consumption power.

In this article, we will approach a decolonizer overview, and consequently, we will adopt the paradigm of the Modernity/Coloniality descolonial turn ${ }^{3}$ as a reflexion leitmotiv. The decolonial turn states decoloniality as grounding principle, i.e., the analytical task of reveiling the colonial logic and the prospective task of contributing to the construction of a society where several worlds and knowledges coexist. From this way of thinking would emerge a global political society that disconnects at the present moment of rewesternization and dewesternization (Mignolo, 2011). Having this way of thinking in mind, providing equality to both case studies, Portugal and Brazil, not looking at the colonizer with superiority, nor repressing the colonized, we will be able to look at diaspora and its cultural representations in the media refusing to perpetuate history as dominating thought.

Mignolo (2013) claims that common sense assumes that people have nothing in common and only relate to each other for economic purposes, thus making them unable to stay together for long. Setting off from Mignolo's subject-matter, could the common space between Portugal and Brazil, i.e., Lusophony, exist as a place for sharing cultures and raising distinct diasporas? Should we consider a real existence of a Lusophone culture, or simply an ensemble of fragmented cultures belonging to Portuguese-speaking

\footnotetext{
${ }^{2}$ About seven million Brazilians have moved from $\mathrm{D}$ and $\mathrm{E}$ social classes (low middle class and low class) to $\mathrm{C}$ class (middle class) between 2005 and 2006 (Canzian, 2007). Statistics estimate that, during the two Lula da Silva's terms of office as President, middle class has grown $14 \%$, corresponding to a 35 million people social class rise (IBGE, 2013).

3 The decolonial turn is a founding principle proposed by the Modernity/Coloniality group (M/C), a network of LatinAmerican thinkers, mainly radicated in the USA, settled at the end of the 9o's and inspired by the Latin-American subaltern studies group founded in 1992. The M/C group does not place itself as the Latin-American post-colonialism but does admit being keen on the rescue of $19^{\text {th }}$ century Latin-American political movement. According to Mignolo (2011), coloniality is the dark side of the eurocentric modernity. Linked to this sense of modernity we find coloniality, as both concepts are considered to be separate parts of the same phenomena, which emerged at the time of the Discoveries did (Faria \& Wanderley, 2013). According to this argentinian author, coloniality intends to release the world from the idea that part of the world's 'inferiority is a fiction created to dominate it was just bad luck having been born in that place, as human beings lose equality just because they were born there" (Mignolo, 2013, p.135). The descolonial turn considers that the modern world has rised on top of colonialism, imperialism and slavery.
} 
countries? And are radio shows aiming the Portuguese diaspora in Brazil representing an abidance behaviour towards coloniality and shaped by that modernity rethoric mentioned by Walter Mignolo?

These research questions will be investigated through comparative analysis of radio models in both case-study countries, considering their present economic and political situations and their influence in the Lusophone culture broadcasting. In the following pages, we will deepen the concept of diaspora, reviewing the role of radio in connecting emigrant communities to their homeland. We will analyse radio shows devoted to Lusophone culture and music produced in Portuguese speaking countries, broadcasted both in Portugal and Brazil. The expression of Lusophony in Portuguese and Brazilian public radio stations will be analysed through the eye of media exposure of Lusophone culture's elements in its most diverse artistic expressions. Observing the presence of Brazilian and Portuguese music in public service broadcasting, interviewing radio personalities and researchers, and taking part in discussions about the expression of Lusophony and other events that approach the topic of Lusophone space in Portuguese and Brazilian broadcasting.

In this article, we expect to approach the point of view of decoloniality on the Portuguese diaspora in Brazil, in a geographic space where the aixes of coloniality and migration have been inverted and reverted throughout decades and centuries. Firstly, one of our goals is approaching the concept of Lusophony as a colonizing space - because it has been rooted in North versus South epistemologies - as well as a colonized one - because it happens to be a linguistic union that has redunded in a group of countries that argue about financial and commercial transactions in the same language. Secondly, another goal is looking at the radio as a media agent with decolonizing potencialities, given its high flexibility, distribution transversality, and decreased permeability to economic concerns. This happens because the radio is historically a less powerful media among the public sphere, and therefore, less interesting to economical and political elites. Lastly, in this paper we will focus first on the concept of Lusophone culture and the contribution of migration movements to a certain perception of Lusophony. Moreover, we will proceed with a deeper analysis of radio as a media channel and radio shows about Lusophone culture - and also more specifically Portuguese culture shows produced and broadcasted in Brazil.

In order to study migrations flows, diasporas and their interaction with the radio, we performed personal interviews to several social actors considered relevant to the topic in Brazil, namely radio producers and presenters, listeners and communication reserachers. Interviews, participant and non-participant observation took place from January 2014 to January 2015.

\section{MigRATION FLOWS INSIDE THE LUSOPHONE SPACE AND CULTURE}

Thinking about the Portuguese identity through its culture, bridging the past and the present, necessarily means thinking about "the Portuguese language space "interidentities'" (Santos, 2003, p. 8), thinking the extra-border space built by Portugal throught 
the linguistic heritage that created. As mentioned before, our theoretical framework is the decolonial turn and what Baptista (2013) calls the "colonialist/post-colonialist/decolonialist thought" (Baptista, 2013, s.p.). Only around the decoloniality symbolic place (Quijano, 2012; Mignolo, 2011; Maldonado-Torres, 2011; Grosfoguel, 2007) will we find the necessary concepts to analyse our object of study: diaspora, emigrant communities, feelings of belonging to a country or nation, the local culture without a dominant culture.

Portugal sees the Portuguese language as the great legacy of post-colonial territorial borders. However, what has been united due to language has been divided by culture. And what is divided by culture is summed by miscegenation (Holanda, 1976; Freyre, 1947; Munanga, 2008). Therefore, also fuzzy ${ }^{4}$ cultures (Santaella, 2011) are a product of the amplitude of this Lusophone space: "new Lusophone synthesis - in race, arts, life" (Chaparro, 2000, s.p.). Since the end of Salazar's regime, and until the mid $21^{\text {st }}$ century, Portugal has experienced the passage of migration blows towards its territory, inverting the Discoveries' stream:

It is in differences (between histories, cultures, people, groups) that Lusophony takes place and stands out. It is through creative and lucid observation, by noticing differences, that we develop the ability to discover the Other, to understand and interact with him or her. Differences show up in cities, villages, hamlets. In local spaces, through human presence and intervention, that history is built up and takes its course. History decided that, in recent years, Portugal would become an attractive space for differences. And that happens thanks to the inversion of migration flows: Africa, Brazil, East Timor, Portuguese speakers from everywhere seek Portugal to build and rebuild their lives, sometimes not cordially but always transforming. (Chaparro, 2000, s.p.)

Discoveries were commanded by the Portuguese caravels in the varguard of exploring the planet, thus beginning the first globalization entreprise (Rodrigues \& Devezas, 2009), even if set up in a non-continuous way, as at the time there were no communication channels that would promote its solidification. At the time, globalization's constructive possibilities - besides learning about the Other that is overseas, the start up of knowledge transference to other parts of the world and the information dissemination - began an attempt of padronization and standardization of symbolic elements of local cultures. Globalization also represents an extraordinary gathering of possibilities supported in new facts. We highlight here two of those new facts. Firstly, the huge and dense mixture of people, races, cultures and aesthetics that - even with huge differences and assymetries - are being produced in every continent. This miscegenation strongly supports other cosmovisions that jepardise Western rationalism. Secondly, new technologies are being more and more framed by subaltern sectors making it possibile to create a true 'sociocultural revenge': this means building contra-hegemony across the world (Martín-Barbero, 2014).

\footnotetext{
${ }_{4}^{4}$ Fuzzy, a word coming from anglosaxon language, may be translated into Portuguese as enveiled.
} 
Assuming that Portugal is the Lusophone space's geodesic mark (because it is the craddle of the Portuguese language) has generated a number of misconceptions with regards to Lusophony and the concept of 'Portugality'. Besides a disguised union filosophy in the globalization era, the Lusophone space is not a 'misunderstandingless' place (Martins, 2014). One of these misunderstandings is the Portuguese centrality misconception, based on an imperialist view brought up by Salazar's regime, playing a role in a neo-colonialist perpective of the old empire's reconfigured narratives. The luso-tropicalism, based on the idea of 'soft' colonisliam, is also one of the misconceptions. Finally, the misconception of 'a narrative of a regretful history (...) with the excuse of saving the memory belonging to a colonial past' (Martins, 2014, pp. 26-27). Therefore, in order to better explain all these misconceptions, and taking Lusophony out of the diplomacy, politics and economic transactions, 'we need stronger politics of Lusophony, because we are not yet Lusophone" (Couto, 2009, p. 96).

For all these reasons, Lusophony politics will have to be necessarily structured as cultural politics and not purely economic or commercial:

Well, culture is the way men connect with reality, i.e., their singularity, unicity. It is the production of meaning that creates a group's identity, implying creation and symbols' reprodu"ction. A poem by Drummond, a paiting by Portinari, a narrative by Guimarães Rosa, a popular ritual, fashion, all of these are symbolic appropriations of reality. They are generators of meaning, of cultural happenings. That is not odd to power institutions, or in Western modern society. Culture is enrolled in social and economic facts and it also reproduces social relationships, (ideologically) imposing adaptation rules of individuals inside the dominant economy, legitimating hegemonic structures. (Sodré, 1991, p. 39)

This portrait belongs to cultural flows happening through the Lusophone space, where relationships between national states are themselves crossed by elements from local, national and also global cultures (Haussen, 2005). Autonomous nations that connect without the distance of of the idea of "foreignness" - thanks to the fact that they communicate in the same language. Lusophone culture is therefore based on those essential characteristics: sharing the language through different cultural frames ${ }^{5}$, with a network strategy, transposing borders through different communication platforms that share content which is accesible to everyone that is a fluent speaker of their country's formal official language. Knowing that this paper focuses on radio, we will consider as network the sound space of hertzian waves and also of internet, in the case of webradios.

Just like the paradox that characterizes South countries' cultures, also the access to culture (in the globalization panorama), practices a double dictomic function. On the one hand, it cristalizes the position of elites, as they own the privilege of access to cultural industries. On the other hand, the cultural mainstreaming promoted by globalization

${ }_{5}^{5}$ Cultural frame is the set of practices or cultural representations connected to everyday life situations experienced by its possible insiders (Goffman, 1974). 
has also easened the acess of less privileged layers of society, for instance, in the case of free cultural shows. Culture is also formatted by historic and scientific processes, in the sense that science is able to answer social needs through new models of cultural expresssion - cultural conscienceness and historic evolution express the human being's dynamism (Ortega \& Gasset, 1983).

The communication acess popularization phenomena has massified culture. In the view of the members of the Frankfurt School - such as Adorno or Horkheimer - the intense verticalization of this process and its indoctrinator character can be better analysed through the concept of 'cultural industry'. Umberto Eco has always been critical about the Frankfurt School's paralizing proposals so he chose to use the term 'mass culture'. However, Eco understands that one has to choose between both concepts so that we can discuss the matter of contemporary culture. 'Popular cultures are, by definition, cultures belonging to subaltern social groups, built in a dominance situation' (Cuche, 2002, p. 148). But being culture mainly widespread nowadays by cultural industries, great part of access to cultural products is mediated by the capitalist strategy, i.e., by paying a certain fee for a service that is adquired. Culture is then nowadays a product that, just as the rest of consumption society's elements, has to be sellable. For that reason, society demands culture to be an attractive, seductive, announced and, consequently, popularized - being both definitions of 'popular' valid (popular has 'desired' and popular as 'produced by the people'). And this culture democratization allows us to go back to the origin of the concept and its prime function.

Lusophony represents a set of countries that are united by the language but have long ago been separated by history. If, in the past, the Lusophone space has been built on belic conquers of territory, today that conquer is performed through cultural interactions that become more or less intense according to economic and political relationships established between countries. These connections inside the Lusophone world remains at a diplomatic level, distancing culture from the people, keeping the original definition of culture as devoted to elites. Paulo Freire (1979), who inspired a pedagogical theory of social and cultural action as a way of releasing people from oppressive structures, inspires us to look at culture as an active agent in the search of a common identity, and consequently, a development and social change agent.

Cultural products, such as music, dance or literature, to be turned into mediated cultural products, should fit (not necessarily but almost always) this cultural marketing 'product that sells' strategy. However, one should also consider the other side, the bourdian approach of culture as a revolutionary element able to change the status quo (Bourdieu, 1987). This is also the main idea of the concept of culture in the post-Iluminism era: '[culture] Seeks to eliminate classes; generalize everywhere the best that one thinks and knows, making all men able to live in an atmosphere of light and sweetness' (Arnold, 1869, p. 49). Information and communications technology (ICT) has also been part of popular cultures cristalization, spread as ever before - and, for this reason, standardized as ever before.

This mediatic dissemination has launched the rise of visibility of several popular culture phenomena, just like the Portuguese and their caravels had done in the Discoveries 
era. Popular culture, also thanks to the spread of ICT, is highly visible. We own more visibility mechanisms comparing to our ancestors - therefore, we know more about each other than the ones that came before us (Betts \& Bly, 2004). Besides, the visibility of the Other is enhanced by electric energy propagation and consumption, which makes the screen (the most important digital communication system tool) work, dialectically with regards to ICT, as these devices are more and more interactive. The visibility of the Other happens in a "demography of surfaces" reasoning (Betts \& Bly, 2004, p. 7), where electricity and wifi, moderated by the screen, make culture less tangible and more shareable. More, quicker and clearer seems to be the present leitmotiv of the relationship media/ popular culture.

However, when we return to the paradigm of 'word' - and not of the 'eikon' - as the main support of media communication, we readopt the element that has always made diaspora solidify in its new address, without losing its country of origin's references: language. Etimologically, Lusophony sets the existence of a Portuguese phoneme - a polimorfic phoneme, with multiple accents, several ways of writing, and even different significants. "The Lusophony space, not only its obvious linguistic meaning, but also its cultural room, is a multipolar, intrinsically decentered space - and even maybe an exploded one" (Lourenço, 1999, p. 188). The Portuguese language's 'pluri-loudness', spoken by different African, Brazilian ou even Galizian accents (from which the language historically descends), expands a sense of polyphony. The presence of other texts inside one text (Bakhtin, 1999), or in this case, several subtexts in the same language but pronounced by different accents, and thus different sounds. Next, we will head to the stage of sound, in order to reflect on radio presence among Portuguese descendent communities in Brazil.

\section{RADIO AS AN AGENT OF POPULAR CULTURE}

Massive transmission of a certain people or community's identitary elements has transformed popular culture in mediatized culture. In the 80's we had already noticed with Baudrillard (1987) the profound relationship between human being and the screen - control panel of the intersection of an influence network. This media relationship, or mediatized relationship (assuming that media are so institutionalized in modern society's lives that it is media themselves generating events and not only conveying them), is close to what the author has defined as 'communication ecstasy' (1987). This concept is an obscenity state, as it reveals the human being creation, registering the individual's freedom of expression according to porn spelling.

As the spectacle prevails, radio seems to be living on the margins of this phenomena, as its visual component belongs to the field of imagination and not to the screen itself. Radio is also considered to be the traditional medium that best adapted to the new digital communication paradigm, as it is a sound medium of considerable flexibility. Radio is a medium that still cultivates less immediacy in its processes, compared to mobile devices. What has actually been accelerated by ICT in radio is interactivity between issuers and receptors. Radio is both a popular culture producer and relay. Even if the radio is 
a moderator between speaker and listener, not existing a physical placement for symbolic exchange between issuers and receptiors (Sodré, 1991), there is room for mediated interaction through other technological platforms, such as letter, telephone, e-mail, social media, among others.

Radio shows produced for diasporic communities belong to the perception of 'mediascape' (Appadurai, 1996) as 'deterritorialized imagined communities' (Anderson, 2005). These radio shows can be included in the 'deterritoriality' flow, as their target is apart from its home country. The goal of these radio shows are exatly 'reterritorializig' the immigrant community in the culture of the country that has been left behind. Affection and proximity are emotions normally connected to the radio, and are reproduced by elevating the Portuguese culture and replicating this complimenting tone throughout the shows. The sound seems to adense commotion related to the country that has been left behind, the nostalgic thought about the nation that is lost when ones decides to emigrate.

The appaduraian concept of 'mediascape' - 'mediascapes refer both to distributing electronic capacities of producing and disseminating images (newspapers, magazines, TV stations and cinema studios) (...) and to the world images themselves, produced by those media' (Appadurai, 1996, p. 35) - supports an optimistic perspective of the role of media in returning the space lost by those deterritorialized communities. This rehimburse is executed through the global diffusion of content through communication technological devices that easen - or even allow - reception of these contents by communities fisically distant. In a more negative perspective we find Meyrowitz (1985), who states that media have been creating 'place meaningless' communities. This would harden the constitution of a diasporia and its feelings of belonging, and the common selfrepresentation this implies (Cahen, 2013). Proximity, affectiveness and connection to the listener make the radio able to reproduce, through its mediatic genesis, the local character of their homeland - versus globality - searched by communities that are away, also assuring 'relocality' in the country they live in:

Today I believe that locality is a place where circulation processes, i.e., constant changes happen in order to produce daily life - another word that is very important and has a lot to do with affection, feeling, subjectivity. Rephrasing, I believe that subjects produce the local and everyday life, and locality is produced by subjects. Nowadays there is a circle that cannot be understood without being placed in the context of this elements circulation. Locality becomes an appropriation of globalized circulation elements that produce their subjectivity paralelly to their locality. (Appadurai, 2009, p. 134)

In the countries where this analysis takes place - Portugal and Brazil - there are consistent phenomena coming from the diaspora's institution. The cultural representation of these phenomena happens, for instance, through staging the Portuguese folklore in events of the Portuguese emigrant community in São Paulo ${ }^{6}$. This selection of cultural

${ }^{6}$ The Portuguese folklore festival at 'Adega da Lusa', in the Portuguese Sports Association in São Paulo; the activities taking place at the São Paulo's Portuguese House; among other. 
elements among the circles of Portuguese diaspora in Brazil takes us to the concept of otherness. Being open to discovering the Other is the only way of understanding Lusophone culture's repercussions in the globalization era of post-colonialism, where migration flows have been inverting the routes that originally established territorial borders of Lusophony (Chaparro, 2000). Is the present ontologic formulation of the Lusophone culture a mimetic representation of the Portuguese post-colonial culture, or could it be closer to the concept of 'decolonial turn'?

It is within the global localization perspective that many authors, namely Barker, talk about complementarity between global media markets and regional media markets. This is an important regionalization movement, based on common language, culture and history. This phenomena, in globalization, would emphasize cultural differences ('cultural discount'), but it would, at the same time, allow economic and symbolic rentabilization in those cultural differences through the creation of market niches and developments anchored in language, history and shared imaginaries. These media and mediatized products would work both as globalizing agents - by proposing behaviours, consumption ways and global symbolic values - and as regional deepening, recovering or rehinforcing symbolic spaces and local cultures. (Ferin, 2007, p. 102)

Is the present Lusophone culture ontological formulation a mimetic representation of Portuguese post-colonial culture? Or does it get closer to the concept of 'decoloniality'?

\section{Representations of Portugal in the Radio aimed at the portuguese diaspora: CONTEXT AND THE BRAZILIAN CASE}

One of the first radio shows produced in Portugal for the Portuguese diaspora was in Emissora Nacional station, in 1937, and was named "Half an Hour of Saudade7". It targetted, initially, codfish fishermen sailing through the seas of the Newfoundland (Canada), later the emigrant community and lastly soldiers that were fighting in Africa during the Portuguese colonial war (1961-1974): 'There are thousands of souls awaiting for the moment they can listen to our broadcasting' (Queirós, 1937 cit. in Moura, 2010, p.6). Likewise, in the last few years in Brazil great number of radio shows locally produced for the diaspora popped up, i.e., produced at the emmigrants' destiny country. This seems to be the most common broadcasting strategy after the end of the Portuguese dictatorial regime of Salazar:

National Broadcasting's radio show worked as a connection link to the country. Later, this link somehow diluted and ended up being replaced by shows created by the Portuguese community living in Argentina. (...) We

\footnotetext{
7 'Saudade' is a Portuguese word that has no literal translation into English. It is a feeling of nostalgia that one gets when something or someone he likes or loves is apart. This emotion has been historically connected to the Portuguese culture and has been widely used in Fado lyrics.
} 
deduce that they were helpful in fighting isolation and sort of helping recreating origin. These radio shows contributed to the understanding of imaginary, communitary and identitary links between anonymous subjects that shared the use of the same cultural product and also needed to share their origin. (Moura, 2010, p. 15)

At the time, as still today, these shows' goal was deepening the relationship of the Portuguese community to the country, relocalizing it in a place of interest to the country that was left behind and placing it towards the original culture and its revivalist spaces. Assuming this common goal - sharing an origin -, we will deepen the topic of how origin is perceived. How is Portugal represented in Brazilian radio shows produced for the Portuguese diaspora? Which symbolic elements are more recurrent in the sound representation of the origin country? Is there a diaspora common review, tranversal to the radio medium? Or what are the limits of the hole that separates the different portraits of a 'past-nation'?

Brazil-Portugal migration history is grounded by iconic episodes of the history of both countries and also by flows that used to be unilateral and then became bilateral. Pedro IV of Portugal, first emperor of Brazil, could be considered the first Portuguese emigrant in the country that he made independent himself. In the 17th century, Portuguese emigration towards Brazil became significant and even more in the 18th century, when mining strongly developed in the colonial economy. After the independence, in 1822, Portuguese emigration stagnated, and it started again in the second half of that same century, reaching its peak in the first half of the 20th century: 25,000 Portuguese were arriving annually to Brazil. (IBGE, 2000)

Estimates say that around five million Brazilian people are direct descendents of the Portuguese, which means they are able to adquire the official nationality (Silva, 2006). Therefore, we conclude that there is cultural and historical room for radio shows produced for the Portuguese diaspora and emigrant community in Brazil. Attempting to map this radio genre, we found several shows about Portugal across the different Brazilian states. Even if this mapping is still under construction, and thus cannot be considered exhaustive, the great majority of these shows are broadcast in stations located in the state of Rio de Janeiro. However, we also identified case-studies in the states of São Paulo, Federal District (Brasília), Paraná, Bahia and Pernambuco.

Starting with Rio de Janeiro, Metropolitana Radio features multiculturality, as it produces shows about several different countries, including Portugal. Shows about the Portuguese culture are broadcast very intensely on weekends. Saturday's program schedule is exclusively about Portugal from 7.30am till 7pm, and on Sundays there are still two Portuguese-inspired radio shows. Other radios shows in Rio de Janeiro with Portuguese content are 'Modern Portugal', 'The Atlantic voice', 'Portugal radio sports', 'Portuguese echos', 'Let me speak', 'Portuguese message' and 'Portugal from North to South', being this last one broadcast for more than 40 years. 
In the state of São Paulo, we found the shows 'Sea Heroes', on Trianon AM Radio, 'Portugal New Trail' on ABC Radio and 'Sailing is needed' on Imprensa FM Radio (all of them are broadcast on Sundays, and all of them in privately-owned stations). These shows have in common the category they all fit into ('varieties'); music (specially Portuguese popular music, Fado and folklore) which takes over around half of the show; selected themes include mainly the Portuguese and descendents of Portuguese community's events, gastronomy, few news on politics and society, football and advertising, specially concerning Portuguese brands or companies; lastly, their presenters, even though they are Portuguese or descendents of Portuguese, have a very strong Brazilian accent, showing a slightly Portuguese accent normally at the end of a few words:

(...) a set of really good productions, where the presenters' Portuguese accent and a Brazilian tone-of-voice are balanced. The mix of accents is the starting point for union in a programming grid which main goal is bringing radio stations as close as possible to the Portuguese community through joyful, emotional and informative programming. (Lepetri, 2011, p. 321)

The double accent also represents a strong hallmark, both in what concerns the presence of two presenters - normally male and female, one with a Portuguese accent and the other with a Brazilian accent (from Rio de Janeiro) - and also the constant switch from Portuguese songs, Fado and regional songs, to Brazilian songs. (Almeida, 2005, p. 3)

Faithful listeners are oftenly mentioned in these kind of shows, as they regularly get in touch with the producers/presenters by telephone or e-mail. Social media are not very often used by listeners yet, and for this reason producers have left them a bit apart (Botelho, 2014; Mendonça, 2014). The conection to the diaspora is evident, in the way that these shows have low audience but high levels of fidelization among the Portuguese and Portuguese descendent community. The only exception is the show 'Portugal, saudade and you', on Capital AM Radio (São Paulo), which is vice-leader of audience in the AM segment in the state of São Paulo, just bet by Globo Radio, according to the audience test for its schedule (IBOPE, 2014).

Concerning Metropolitana Radio in Rio de Janeiro, just $9 \%$ of its listeners are interested in foreign countries radio shows, compared to $45 \%$ who are interested in religious shows, $43 \%$ by music shows and only $3 \%$ who prefer sports shows, according to a poll taking place at the stations's website (Metropolitana, 2015). This result matches a few exploratory observations and interviews ${ }^{8}$ undertaken in São Paulo and Brasília, where does not seem to exist generalized interest in radio shows aiming other countries' cultures besides Brazil - the only exception is, as mentioned before, communities originally belonging to that country. Every case-study referred to until now corresponds to private

\footnotetext{
${ }^{8}$ Study that took place in São Paulo and Brasília from January to December 2014 about Lusophone culture radio shows, particularly the music produced in Portuguese speaking countries. We performed semi-structured interviews, non-participant observation and content analysis to main radio shows about Lusophony.
} 
radio stations which mostly sell part of their schedule to producers of those radio shows, in order to promote Portuguese culture. The only exception is the show 'So much sea', broadcast on Sundays from 6pm to 7pm on National FM Radio in Brasília, one of the eight stations that belong to EBC, the Brazilian public service broadcasting company9. National FM Radio in Brasília broadcasts since 1976 and it was the first station in Brasília to broadcast on FM, coverting the whole Federal District: 'the station that, in the beginning, took the role of assuring communication to the new inhabitants of Brasília that were coming from all over the country to build the new capital of the Republic' (EBC, 2015a, s.p.).

The station focuses on Brazilian music production, with hourly news of about three minutes each, dedicated to national news and other four minutes of governmental information (regarding the Federal District); 'citizen information is placed in two news reports and in short reports throughout programming' (EBC, 2015b, s.p.). Both traditional and contemporary Brazilian popular music are heard in this station (MPB) and also samba, instrumental music, independent music and also productions from local artists, namely coming from Brasília.

In the 'About' section of the station's website, the importance of aperture to international music and culture is mentioned: 'the station also provides room for world music, from both Portuguese speaking and Latin American countries' (EBC, 2015b, s.p,). 'So much sea' is the only public service broadcasting show focused in music written in Portuguese so we can conclude that it is one of the station's strategic shows, as it is directly referred to in the company's website. The show, besides being broadcast Sundays, is also shaped as a daily rubric from Monday to Friday at $8.15 \mathrm{am}$ and $10.30 \mathrm{pm}$. This rubric consists of one of the songs that was part of last Sunday's complete show. Even if most of the content in the show concerns Portuguese music by Portuguese artists, the show is assumedly about Lusophony (mentioned in its jingles ${ }^{10}$ ), and it also includes artists from Cape Verde, Angola and Mozambique.

Given this positioning, 'So much sea' is a highlight in its segment. Because it is broadcast in the public station's strategic programming, there is no concern about audience levels (Senna, 2014) and the producer is totally free to select the contents she finds the best (Mendonça, 2014). This freedom seems to be more conditioned in private radio stations, due to the fact that producers pay for their own schedule and depend on advertising to keep the show running. For these reasons, they prefer to connect the Portuguese and Portuguese descendent community preferred cultural products (especially Fado, folklore and popular music), as oftenly the community itself is the main source of funding through advertising or donations.

\footnotetext{
9 In Brazil, public service broadcasting has only been formally instituted since 2007 with the creation of EBC ("Empresa Brasil de Comunicação', i.e., Brazil's Communication Enterprise) and its seven radio stations: MEC AM and FM Radio, Nacional AM Radio in Rio de Janeiro, Nacional FM Radio in Brasília, Nacional AM Radio in Brasília, Nacional Radio in Amazonia and, lastly, Nacional Radio in Alto Solimões. According to the Latin-American's Broadcasting Observatory's data, more than 500 radio stations all over Brazil reproduce part of EBC's programming, especially news reports (Observatório, 2014).

10 Some of the show's jingles are: 'So much Sea, the richness of the Portuguese speaking countries' music'; 'So much Sea, the Portuguese speaking countries' community music'; 'So much Sea, the Portuguese speaking countries' sound language'; and only one with direct reference to Portugal: 'So much Sea, all the tradition and beauty of Portugal's music'.
} 
On the contrary, in 'So much sea' criteria are mainly two: 'quality in what concerns contemporary Portuguese language music' (Mendonça, 2014) and the producers' musical culture. Therefore, the show is pretty much defined by her personal touch, as she enjoys this freedom of creation and editing authonomy: "I just play what I enjoy listening to' (Mendonça, 2014). Musical selection is directed to a more literate audience, and for this reason, the presenter seeks to include more elitist music instead of popular music, following more intellectual guidelines. She mentions intervention music, the new generation of Portuguese Fado, singers and songwriters from the Portuguese history of music and she gives all of them the generic 'contemporary Portuguese music' label. Still, more popular music genre can be included when associated to artists that the producer and presenter finds relevant: 'I play Fado which is the genre that everyone wants to listen to because everybody associates Portugal to Fado only' (Mendonça, 2014). One of the goals claimed by the producer is spreading the word of Portuguese music so she is willing to play different music genres and artists that do not correspond to stereotypes usually attributed to Portugal.

Still, we identified a couple of characteristcs that are common to every radio show about Lusophone and Portuguese culture. To start with, accessibility is one the criteria for music selection, as each of the producers presents a personal discography which works as database for selecting music to play in the show. Moreover, there seems to be a reduced level of strategic consciousness when shaping the show, i.e., every show is produced almost without guidance from the station's board of directors. This very light intervention on these shows makes them become media products strongly marked by spontaneity.

In other words, no cultural product is odd to me; with none of them I feel $100 \%$ identified, and certainly not enough to deny other pleasures. I feel at home anywhere, even if there is no place I can call home (maybe because of that). It is not as much the confrontation of (refined) taste against (ordinary) taste, but omnivorous against univorous, i.e., the availability to consume everything agains excessive selectivity. (Bauman, 2011, pp. 8-9)

According to what has been mentioned, Brazilian radio shows about Portuguese culture seems to be closer to the baumanian concept of "univorousness" than omnivorousness, as diaspora does not seem to be available to consume every music product from the Portuguese culture, preferring the ones that are directly associated to their imaginary from their past in Portugal (Monteiro, 2014). In this imaginary we can include cultural products that are not representative of the Portuguese contemporary cultural reality, as they suffer from reduced selectivity, simply based on Fado, folklore and light popular music (Botelho, 2014; Cambaúva, 2014).

\section{Conclusions}

According to Bordieu (2010), culture defines class and potentializes social segregation by unveiling a certain social stratification that divides classes and human beings in 
taste and aesthetics drawers. Well, analysing the concept of culture implies deepening roots in a set of local, identitary and communitary elements, signs understood by part of the population that feels portraited in this symbolic frame. The concept of Lusophony consists of a unifying attempt of gathering what the decolonizing process had divided. Observing Lusophony through the concept of Lusophone culture imposes as a challenge to the universal analysis of all the Lusophone space representations. Music, literature and paiting are, therefore, languages that make it possible to see Lusophony as an intercultural synthesis of a linguistic space that has invaded territories to which, fisically, did not belong.

Media and their representations of Lusophony end up as being a consequence of obliving determined countries in the context of the Lusophone space - such as East Timor, a small country rarely quoted in representative contexts of Lusophony. Through different phonetic representations, accents become the colour of diversity in the Lusophone space, mediated by the sound of radio. Diaspora represents itself in radio shows that assume a role of localization and relocalization. Afectiveness, and the proximity with the listener, makes the radio able to reproduce locality in a media instancy - versus globality - search upon by communities absent from their country of birth, also assuring 'relocality' in the country where they live in. This 'relocality' seems to attribute a double connection both to the diaspora's country of origin and host country.

We have argued that Brazil, in a media context, does not cultivate interest on the culture of the Other. This absence of the diverse may be connected to the huge territorial and populational dimension of the country: there are many "Brazils". However, it can also be linked to the weak penetration of the public service broadcasting, which is responsible for promotting diference, diversity, multiculturality and internationalization of culture. Creating the EBC was not enough to weaken the domain of the 'society of spectacle' (Débord, 1967) in the hegemonic context of private media among the Brazilian communication system. Nevertheless, it has certainly potencialized the existence of alternatives to the current hegemonic system, allowing to diversify media products and to switch social representations in the media.

Radio shows inspired in the Lusophone culture in Brazil reflect a certain social detachment, anchored in a distance of the broadcasting context. Themes approached only intend to be relevant to the Portuguese community in Brazil or Brazilian social groups that are somehow interested in the Portuguese culture, bestowing a precept of nationality and, therefore, a community sense. In Brazil, concerning the private radio stations that were observed, the show's producers buy their own space. We consider then that, in Brazil, the radio category analysed is commercial or profit-oriented, excepting 'So much sea', from EBC/National FM Radio in Brasília. This show makes a statement starting from its own title - a Chico Buarque's song about the Portuguese democratic revolution -, a choice that reveals a more progressive position by the producers and the station's direction. EBC's show is musically more connected to contemporanity, while Trianon, $A B C$, Capital AM and Imprensa FM relate more to the emigrant community in the country, preferring more popular topics. 
Radio seems to be a simple vehicle for the dissemination of Lusophone popular culture, as these shows have a very simple structure production strategy, and their execution is low cost, easily undertaken by two people only - as it happens in Capital Radio and Trianon Radio. Language used is informal, close to listeners, emotive, flattering the Portuguese culture. Presenters are Brazilians with Portuguese ancestors, or Portuguese settled in Brazil for decades. Their Brazilian accent related to the Portuguese culture topics create a hybrid culture product (Young, 1995), an interpretation of the way Brazilians look at the Portuguese present day society. Besides hybrid, this interpretation is far from present cultural industries settled in Portugal. Excluding EBC's 'So much Sea', shows are focused on the diaspora and the relatioship with listeners is extremely close, present and important for producers. Many of the contents mentioned are requested by listeners themselves, who contact directly with the show's producers through telephone and e-mails.

Even if only FM radio shows were analysed, there is a research route to be explored, which concerns webradios. Internet potentializes the expansion of radio across borders, namely to other countries that also belong to the Lusophone world. This fact opens here a chance for extending the Portuguese radio medium to other countries, taking advantage of a common language and of the wide Lusophone space to enlarging its action field, and consequently opening new research routes in the field of Radio Studies.

\section{REFERENCES}

Almeida, A. (2005). Ondas lusitanas: a comunidade brasileira no AM carioca. Retrieved from http:/ www. jornalismo.ufsc.br/redealcar/cd3.htm.

Anderson, B. (2005). Comunidades imaginadas. Lisboa: Edições 70.

Arnold, M. (1869). Culture and anarchy: An essay in political and social criticism. Londres: Smith, Elder \& co.

Appadurai, A. (1996). Modernity at large. Minneapolis: University of Minnesota Press.

Bakhtin, M. (1999). Marxismo e filosofia da linguagem. São Paulo: HUCITEC.

Baptista, M. (2013). Apresentação: Re-imaginar a lusofonia ou da necessidade de descolonizar o conhecimento. Retrieved from http://estudosculturais.com/congressos/ivcongresso/apresentacao.

Baudrillard, J. (1987). The ecstasy of communication. Retrieved from http://iris.nyit.edu/ rcody/Thesis/ Readings/The\%20Ecstacy\%200f\%20Communication\%20-\%20Baudrillard.pdf.

Bauman, Z. (2011). A cultura no mundo líquido moderno. São Paulo: Zahar.

Betts, R. \& Bly, L. (2004). A history of popular culture. Londres: Routledge.

Bourdieu, P. (1987). What makes a social class? On the theoretical and practical existence of groups. Berkeley Journal of Sociology, 32, 1-17.

Cahen, M. (2001). Pays lusophones d'Áfrique. Sources d'information pour le devéloppement. Bourdeaux: Ibiscus.

Cahen, M. (2013). Imperial migrations: Colonial communities and diaspora in the Portuguese world. Londres: Palgrave Macmillan. 
Chaparro, C. (2000, s.d). O Brasil oficial pouco liga à lusofonia. Jornal do Ribatejo.

Couto, M. (2009). E se Obama fosse africano? Lisboa: Caminho.

Cuche, D. (2002). As noções de cultura nas ciências sociais. São Paulo: Edusc.

Canzian, F. (2007). Crescimento tira milhões das classes D e E. Retrieved from www1.folha.uol.com.br/fsp/ dinheiro/fi1612200702.htm.

Débord, G. (1967). A sociedade do espetáculo. Retrieved from http://www.ebooksbrasil.org/eLibris/ socespetaculo.html.

EBC Rádios (2015a). Retrieved From http://radios.ebc.com.br/sobre.

EBC Rádios (2015b). Sobre a Rádio Nacional FM Brasília. Retrieved from http://radios.ebc.com.br/ nacionalfmbrasilia/sobre.

Faria, A. \& Wanderley, S. (2013). Fundamentalismo da gestão encontra a descolonialidade: repensando estrategicamente organizações familiares. Retrieved from http://www.scielo.br/pdf/cebape/v11n4/07.pdf.

Ferin, I. (2007). Media, imigração e minorias étnicas. Retrieved from http://www.oi.acidi.gov.pt/docs/Col_ EstudosOl/OI_28_act.pdf.

Freire, P. (1979). Educação e mudança. Rio de Janeiro: Paz e Terra.

Freyre, G. (1947). Uma interpretação do Brasil. Rio de Janeiro: Biblioteca Nacional.

Goffman, E. (1974). Frame analysis: An essay on the organization of experience. Boston: Northeastern University Press.

Grosfoguel, R. (2007). The epistemic decolonial turn: Beyond political-economy paradigms. Cultural Studies [Vol. Especial], 21(2-3), 211-223.

Holanda, S. (1936). Raízes do Brasil. Rio de Janeiro: Companhia das Letras.

IBGE - Instituto Brasileiro de Geografia e Estatística (2000). Censo Demográfico 2000 - Características Gerais da População: Resultados da Amostra. Retrieved from http://ftp.ibge.gov.br/Censos/ Censo_Demografico_200o/populacao.

IBGE - Instituto Brasileiro de Geografia e Estatística (2013). Projeção da População. Retrieved from http://ibge. gov.br/home/estatistica/populacao/projecao_da_populacao/2013/default.shtm.

Instituto Brasileiro de Opinião Pública e Estatística - IBOPE (2014). Rádio Recall - EasyMedia4. Disponibilizado por correio eletrónico pelo departamento de Operações Comerciais da Rádio Capital AM (São Paulo).

Lepetri, P. (2011). O rádio e a relação migratória Brasil e Portugal. In M. Martins, R. Cabecinhas \& L. Macedo (2011). Anuário Internacional de Comunicação Lusófona - Lusofonia e Cultura-Mundo (pp. 321-330). Retrieved from http://www.lasics.uminho.pt/ojs/index.php/anuario/index.

Lourenço, E. (1999). A nau de Ícaro: Imagem e miragem da lusofonia. Lisboa: Gradiva.

Martín-Barbero (2014). Tudo o que sabemos, sabemo-lo entre todos: aquela segunda oportunidade sobre a terra - algumas palavras para não faltar completamente. Revista Lusófona de Estudos Culturais, 1-2, 4-6.

Martins, M. (2004). Lusofonia e luso-tropicalismo. Equívocos e possibilidades de dois conceitos hiperidentitários. Visages d'Amérique Latine, 3, 89-96. 
Maldonado-Torres (2012). Decoloniality at large: Towards a trans-americas and global Transmodern paradigm. Journal of Peripheral Cultural Production of the Luso-Hispanic World. Retrieved from file:///C:/ Users/Teresa/Downloads/eScholarship\%20UC\%20item\%2058c9c4wh.pdf.

Meyrowitz, J. (1985). No sense of place. Oxford: Oxford University Press.

Mignolo, W. (2010). Desobediencia epistémica: retórica de la modernidad, lógica de la colonialidad y gramática de la descolonialidade. Buenos Aires: Del Signo.

Mignolo, W. (2013). Descolonialidade como o caminho para a cooperação. Revista IHU Online, 431, 21-28.

Ortega Y Gasset, J. (1958). La rebelión de las masas. Madrid: Revista de Occidente.

Rodrigues, J. \& Devezas, T. (2009). Portugal: o pioneiro da globalização: A herança das descobertas. Vila Nova de Famalicão: Centro Atlântico.

Santaella, L. (2011). Percepção: fenomenologia, ecologia, semiótica. São Paulo: Cengage.

Silva, K. (2006). A nação cordial: Uma análise dos rituais e das ideologias oficiais de "comemoração dos 500 anos do Brasil". Revista Brasileira De Ciências Sociais, 18(51), 141-194. Retrieved from http://www.scielo. $\mathrm{br} / \mathrm{pdf} / \%$ oD/rbcsoc/v18n51/15990.pdf.

Sodré, M. (1991). O Brasil simulado e o real. Rio de Janeiro: Rio Fundo.

Young, R. (1995). Colonial desire: hybridity in theory, culture and race. Londres e Nova lorque: Routledge.

\section{Personal Interviews}

Botelho, I. (2014), São Paulo, 28/06/2014 e 21/11/2014.

Cambaúva, A. (2014), São Paulo, 29/06/2014 e 07/12/2014.

Mendonça, J. (2014), Brasília, 25/07/2014.

Monteiro, T. (2014), Rio de Janeiro, 26/11/2014.

\section{FUNDING}

Research supported by POPH/FSE - SFRH/BD/95915/2013.

\section{BIOGRAPHICAL NOTE}

Teresa Costa Alves is graduated in Communication Science at the Nova University of Lisbon and Master in Translation at the same university. PhD candidate in Communication Science at Minho University, presently preparing a thesis on radio and the Lusophone world. Visiting Scholar at São Paulo University and University of California, Berkeley in 2014 and 2015. Radio personality since 2003, presently as producer and presenter at Renascença Radio.

E-mail: teresa.alves@rr.pt 
Instituto de Ciências Sociais da Universidade do Minho, Campus de Gualtar, 4710O57 Braga

* Submitted: 10-04-2015

* Accepted: 02-07-2015 